Fakultas Hukum Universitas Lancang Kuning, Jalan Yos Sudarso KM 8 Rumbai Pekanbaru, Riau,

Kode Pos 28266. Telp: (+62761)-51877

E-mail: jurnal.respublica@ac.id

Website: https://journal.unilak.ac.id/index.php/Respublica

\title{
Penetapan Wilayah Adat dan Masyarakat Hukum Adat Desa Penyengat Kecamatan Sungai Apit Kabupaten Siak
}

\author{
Wahyu Damon Prakoso \\ Polisi Republik Indonesia, Email: damonwahyu@gmail.com
}

\begin{tabular}{l} 
Article Info \\
\hline Article History: \\
Received : 13-01-2020 \\
Revised : 22-01-2020 \\
Accepted : 15-02-2020 \\
Published : 28-05-2020
\end{tabular}

Keywords:

Public

Customary Law

Region

\begin{abstract}
The problem that occurs is how the indigenous people of swamps interpret the lack of management territory, the loss of livelihood resources and organize themselves to seize opportunities for management rights. The problem of customary land and indigenous peoples above, the researchers felt the need to study more deeply on the Determination of Indigenous Areas and Customary Law Communities in Penyengat Village, Sungai Apit Subdistrict, Siak Regency, Based on the Minister of Home Affairs Regulation No. 52 of 2014 concerning Guidelines for the Recognition and Protection of Indigenous Peoples.

This type of research is sociological, so the data source used is primary data from interviews, secondary data from libraries and tertiary data from dictionaries, media, and encyclopedias. Data collection techniques are done by observation, interviews, and literature review.
\end{abstract}

\begin{abstract}
Abstrak
Permasalahan yang terjadi adalah bagaimana masyarakat suku asli anak rawa memaknai semakin berkurangnya wilayah kelola, hilangnya sumber-sumber mata pencaharian dan mengorganisir diri untuk merebut peluang hak kelola. Permasalahan lahan adat dan masyarakat adat diatas maka peneliti merasa perlu mengkaji lebih dalam tentang Penetapan Wilayah Adat dan Masyarakat Hukum Adat Desa Penyengat Kecamatan Sungai Apit Kabupaten Siak Berdasarkan Peraturan Menteri Dalam Negeri Nomor 52 Tahun 2014 Tentang Pedoman Pengakuan dan Perlindungan Masyarakat Hukum Adat. Jenis penelitian ini adalah sosiologis, sehingga sumber data yang digunakan adalah data primer dari wawancara, data sekunder dari perpustakaan dan data tersier dari kamus, media, dan ensiklopedia. Teknik pengumpulan data dilakukan dengan observasi, wawancara, dan kajian kepustakaan.
\end{abstract}

\section{PENDAHULUAN}

Sejarah keberadaan masyarakat hukum adat di indonesia telah mengalami rentetan sejarah yang begitu panjang dalam politik hukum adat baik sejak zaman pra kemerdakaan sampai pada zaman kemerdekaan yang memasuki zaman reformasi. Pada konteks reformasi kini, pengakuan masyarakat hukum adat secara konstitusial telah dijamin 
oleh Undang-Undang Dasar 1945 tepatnya pada Pasal 18 B ayat 2 UUD 1945. Secara substansial keberadaan Pasal 18B ayat 2 UUD 1945 menjadi landasan konstitusional pengakuan negara atas masyarakat hukum adat di Indonesia.

Mencermati Pasal 18B ayat 2 UUD 1945 yang mengatur bahwa "Negara mengakui dan menghormati kesatuan-kesatuan masyarakat hukum adat beserta hak-hak tradisionalnya sepanjang masih hidup dan sesuai dengan perkembangan masyarakat dan prinsip negara kesatuan republik indonesia yang diatur dalam undang-undang”. Secara substansi, isi Pasal 18B ayat 2 UUD 1945 menegaskan bahwa Negara telah mengakui dan melindungi Hak Asasi Manusia Masyarakat dengan kriteria yang harus dipenuhi menurut perspektif negara yakni kesatu, masih hidup, kedua sesuai dengan perkembangan masyarakat, ketiga sesuai dengan prinsip negara kesatuan republik indonesia, keempat diatur dalam Undang-Undang.

Menurut Prof. Ni’matul Huda, ada dua hal terkait Kesatuan Masyarakat Hukum Adat (KMHA), yakni selain diakui, juga dihormati. Dua hal ini menegaskan bahwa masyarakat adat mempunyai hak hidup yang sederajat dan sama pentingnya dengan kesatuan pemerintahan lain, seperti kabupaten dan kota. ${ }^{1}$ Eksistensi dan kewenangannya tersebut merupakan hak untuk mempertahankan identitas tradisional dan hak masyarakat tradisional. $^{2}$

Satjipto Rahardjo menyebutkan empat persyaratan dalam Pasal 18 B ayat (2) UUD NRI Tahun 1945 sebagai bentuk kekuasaan negara yang hegemonial yang menentukan ada atau tidaknya masyarakat adat. Negara ingin mencampuri, mengatur semuanya, mendefinisikan, membagi, melakukan pengkotakan (indelingsbelust), yang semuanya dilakukan oleh dan menurut persepsi pemegang kekuasaan negara. ${ }^{3}$

Adnan Buyung Nasution mengatakan, bahwa “Apapun sistem kemasyarakatan yang dianut suatu negara, hak-hak dan martabat kemanusiaan orang perorangan yang hidup di dalam masyarakat itu harus dihormati dan dijamin, supaya manusia itu tetap utuh harkat dan martabat kemanusiaannya." ${ }^{4}$ Hal ini memaknakan bahwa, masyarakat adat adalah masyarakat yg merdeka dan tumbuh dalam ruang demokrasi.

\footnotetext{
${ }^{1}$ Ni’matul Huda, Otonomi Daerah: Filosofi, Sejarah Perkembangan dan Problematika, dalam Republik Desa, Pergulatan Hukum Tradisional dan Hukum Modern dalam Desai Otonomi Desa, (Bandung: PT. Alumni. 2010), 45.

${ }^{2}$ Amrina Rosyada, Esmi Warassih, dan Ratna Herawati, Perlindungan Konstitusional terhadap Kesatuan Masyarakat Hukum Adat dalam Mewujudkan Keadilan Sosial, Kanun Jurnal Ilmu Hukum 20, no. 1, (April 2018): 22.

${ }^{3}$ Satjipto Raharjo, Hukum Adat dalam Negara Kesatuan Republik Indonesia (Perspektif Sosiologi Hukum), dalam Hilmi Rosyida dan Bisariyadi (ed.), Inventarisasi dan Perlindungan Hak Masyarakat Hukum Adat, Komnas HAM, Mahkamah Konstitusi RI, dan Departemen Dalam Negeri, Jakarta, 2005.

${ }^{4}$ Adnan Buyung Nasution, Pikiran dan Gagasan; Demokrasi Konsitusional, (Jakarta: Kompas Media Nusantara, 2010), 3.
} 
Pada sisi penerapan hukum keberadaan pengakuan bersyarat masyarakat hukum adat melalui Pasal 18B ayat 2 UUD 1945 telah berimplikasi besar terhadap rumit dan terlalu prosedural pengakuan masyarakat hukum adat dalam peraturan Per-UU. Salah satunya adalah Peraturan Menteri Dalam Negeri No. 52 Tahun 2014 tentang pengakuan dan perlindungan masyarakat hukum adat. Dalam bab IV Pasal 4 Permendagri No. 52 Tahun 2014, telah mengatur tahapan dan syarat yang harus dipenuhi oleh Masyarakat Hukum Adat sehingga bisa memperoleh kepastian hukum atas hak-hak tradisional, tahapan-tahapan yang harus dipenuhi yakni identifikasi masyarakat hukum adat, verifikasi dan validasi masyarakat hukum adat dan penetapan masyarakat hukum adat. Hukum adat adalah bagian dari hukum yang berasal dari adat istiadat, yakni kaidah-kaidah sosial yang dibuat dan dipertahankan oleh para fungsionaris hukum (penguasa yang beribawa) dan berlaku serta dimaksudkan untuk mengatur hubungan hukum dalam masyarakat. ${ }^{5}$

Pada tahapan identifikasi masyarakat hukum adat, hal-hal yang harus dipenuhi yakni sejarah masyarakat hukum adat, hukum adat, wilayah adat, harta kekayaan dan/ atau benda-benda adat, kelembagaan/sistem pemerintahan adat. Pada poin wilayah adat dan kelembagaan/sistem pemerintahan adat secara substansial pada ketentuan hukum ini belum diatur secara jelas teknis penentuan cara menentukan wilayah adat yang dikuasai oleh masyarakat hukum adat dan atau pun kelembagaan / sistem pemerintahan adat apakah diatur secara stuktural. Hal-hal ini masih belum jelas pengaturannya dalam ketentuan hukum tersebut sehingga hal ini tentu menghambat proses pengakuan dan perlindungan masyarakat hukum adat.

Keberadaan Permendagri Nomor 52 Tahun 2014 dalam merespon Pasal 18B ayat 2 UUD 1945 perlu diapresiasi namun dalam sisi penerapannya kiranya perlu ditinjau kembali sehingga kriterium yang ditetapkan tidak bertetangan dengan nilai-nilai hukum yang hidup di masyarakat hukum adat. Banyaknya kriterium yang bercorak prosedural dalam ketentuan tersebut tentu secara hukum dianggap dapat menghambat proses pengakuan dan perlindungan hukum masyarakat hukum adat di Indonesia. Hal ini tentu bertentang dengan semangat konstitusi masyarakat hukum adat. Definsi tentang masyarakat hukum adat antara satu unsur dengan yang lainnya berbeda-beda. Hal ini berpengaruh dalam seberapa besar kewenangan yang dimilikinya. ${ }^{6}$

Upaya pemerintah memberlakukan pengakuan bersyarat terhadap masyarakat hukum adat tampaknya perlu dievaluasi kembali dalam hal penjabaran nilai-nilai pengakuan bersyarat yang diturunkan melalui Pasal 18B ayat 2 UUD 1945 dalam sejumlah peraturan perundang undangan. Apalagi hingga saat ini belum ada Undang-undang

${ }^{5}$ Nabella Puspa Rani, Penerapan Sanksi Adat Melayu Kerajaan Siak Sri Indrapura Terhadap Kekerasan dalam Rumah Tangga, Jurnal Fikri 1, no. 2, (Desember 2016): 293.

${ }^{6}$ Mochamad Adib Zain dan Ahmad Siddiq, Pengakuan Atas Kedudukan dan Keberadaan Masyarakat Hukum Adat (MHA) Pasca dibentuknya Undang-Undang Nomor 6 Tahun 2014 Tentang Desa, Jurnal Penelitian Hukum 2, no. 2, (Juli 2015): 63-76. 
yang mengatur secara khusus pengakuan dan perlindungan hukum masyarakat hukum adat sebagaimana amanat Pasal 18B ayat 2 UUD 1845. Keadaan yang demikian akan menimbulkan legal chaos didalam Peraturan undang-undangan sehingga berimplikasi hukum makin kaburnya entitas hukum masyarakat hukum adat yang dianggap sebagai subjek hukum yang diakui dan dilindungi oleh UUD 1945 .

Menurut Jimly Asshiddiqie, terdapat empat persyaratan keberadaan Kesatuan Masyarakat Hukum Adat (KMHA), yakni: (a) masih hidup; (b) sesuai dengan perkembangan masyarakat; (c) sesuai atau tidak dengan prinsip Negara Kesatuan Republik Indonesia; (d) sesuai dengan apa yang diatur dalam undang-undangan. ${ }^{8}$ Sementara itu Rikardo Simarmata menyebutkan empat persyaratan masyarakat adat dalam UUD 1945 setelah amandemen memiliki sejarah yang dapat dirunut dari masa kolonial. Persyaratan terhadap masyarakat adat sudah ada dalam Aglemene Bepalingen, Reglemen Regering (1854) Indische Staatregeling (1920 dan 1929) yang mengatakan bahwa orang pribumi dan timur asing yang tidak mau tunduk kepada hukum Perdata Eropa, diberlakukan undangundang agama, lembaga dan adat kebiasaan masyarakat, "sepanjang tidak bertentangan dengan asas-asas yang diakui umum tentang keadilan”.

Provinsi Riau memiliki beberapa masyarakat hukum adat yang mempunyai kelengkapan untuk sanggup berdiri sendiri, yaitu mempunyai kesatuan hukum, kesatuan penguasa dan kesatuan lingkungan hidup berdasar hak bersama atas tanah dan air bagi semua anggotanya. Masyarakat hukum adat Riau berbentuk hukum kekeluargaan seperti Patrilineal, Matrilineal dan Bilateral mempengaruhi sistim Pemerintahan, semua anggotanya sama dalam hak dan kewajiban. Dalam hal ini peneliti ingin menelisik lebih dalam salah satu masyarakat hokum adat di Provinsi Riau yakni masyarakat hukum adat suku asli anak rawa yang berada di Kampung Penyengat Kecamatan Sungai Apit Kabupaten Siak.

Berbagai literatur yang menggambarkan suku-suku asli di Riau tidak ada satupun yang memasukkan Suku Asli Anak Rawa, bahkan publik hanya mengenal 8 (Delapan) suku asli di Riau yaitu Talang Mamak yang berdomisili di sekitar dan dalam taman nasional Bukit Tiga Puluh di Kabupaten Indragiri Hulu dan Kuantan Singingi, suku Petalangan di Kabupaten Pelalawan dan Indragiri Hulu, Sakai di Bengkalis dan Siak, Bonai di Rokan hulu dan Rokan Hilir, Kuala di Indaragiri Hilir, Akit di Bangkalis, Suku Hutan di Kepulauan Meranti, dan Suku laut yang masih berpindah-pindah di kepulauan Riau hingga ke Kepulauan Meranti serta ke muara-muara sungai Indragiri, Kampar dan Rokan.

\footnotetext{
${ }^{7}$ Safrin Salam. Konstitusi Masyarakat Hukum Adat, (Jakarta: PT Pradnya Paramita. 2008), 8.

8 Jimly Asshiddiqie, Komentar Atas UUD 1945, (Jakarta: Sinar Grafika. 2009), 62-63.

${ }^{9}$ Rikardo Simarmata, Pengakuan Hukum terhadap Masyarakat Adat di Indonesia, (Jakarta: UNDP. 2006) 309-310
} 
Selain itu di desa penyengat terjadi penguasaan kawasan hutan atas tanah berskala besar oleh perusahaan hutan tanaman industry dan perusahaan perkebunan kelapa sawit. Perusahaan beroperasi tanpa mendahulukan prinsip FPIC (Free prior inform consent) atau yang disebut dengan keputusan bebas yang didahulukan, diinformasikan tanpa ada paksaan. Hal ini dapat dilihat dalam proses pemberian perizinan kepada investor seakanakan tidak ada dampak negative kepada masyarakat. Terbukti ketika tidak ada sosialisasi terlebih dahulu kepada masyarakat tentang rencana pembangunan oleh perusahaan, salah satu dampak dari pembangunan perusahaan ini mengakibatkan terbatasnya wilayah kelola, pencemaran lingkungan dan hilangnya sumber-sumber mata pencaharian masyarakat. Ketergantungan masyarakat terhadap hutan sangat tinggi, hal ini dapat dilihat dari aktivitas masyarakat yang sebagian besar menjadikan hutan sebagai tempat mencari nafkah untuk menghidupi keluarga, selain hutan sungai dan laut juga menjadi sumber ekonomi bagi masyarakat desa penyengat untuk kehidupan sehari- hari.

Di samping itu masyarakat juga dihadapkan dengan peluang hak kelola dengan adanya penetapan wilayah KPHP Model Tasik Besar Serkap di Provinsi Riau 21 september 2010 oleh menteri kehutanan RI yang menjadi salah satu wujud nyata bentuk desentralisasi sector kehutanan. Wilayah KPHP Tasik Besar Serkap berada dalam wilayah administrasi desa Penyengat dan masyarakat berpeluang untuk mendapatkan hak kelola hutan yang belum dibebani perizinan. Namun tentu saja hal ini tidak mudah dan akan memperpanjang perjuangan masyarakat merebut hak kelola dengan adanya kerjasama antara pemerintah Indonesia dan pemerintah korea selatan berencana menjadikan kawasan hutan tersebut sebagai proyek REDD+ seluas 14.000 ha yang berada dalam administrasi 3 desa, yakni : Desa penyengat, Teluk lanus dan desa Sungai rawa. Ini akan menjadi ancaman kepada masyarakat terhadap keberlangsungan hidup untuk masa depan anak cucu.

Konflik sumberdaya alam / Agraria yang terjadi di Provinsi Riau berpotensi konflik yang lebih besar jika tidak ada penanganan yang serius dari pemerintah. Hal inilah yang terjadi di hampir seluruh kabupaten/ kota yang ada di bumi lancang kuning ini. Salah satu permasalahan adalah terabaikannya masyarakat suku asli setempat yaitu di Desa Penyengat Kecamatan Sungai Apit Kabupaten Siak Provinsi Riau.

Desa Penyengat merupakan desa asli yang terbentuk sejak lama. Penduduk asli Desa Penyengat biasa disebut dengan Suku Asli Anak Rawa. Desa ini secara administrative pemerintahan desa termasuk kedalam Kecamatan Sungai Apit Kabupaten Siak. Secara administratif Desa Penyengat memiliki luas 52.000 Ha dan berada tepat di kawasan pesisir Sungai Siak dengan topografi relatif datar. Selain itu di sekitar desa penyengat banyak ditemukan anak- anak sungai tempat masyarakat mencari ikan, antara lain Sungai Kimas, Sungai Pinang, Sungai Sikicak, Sungai Darak, Sungai Beruang, Sungai Mungkal, Sungai Kimbar, Sungai Sialang, Sungai Dua, Sungai Senabau,Sungai Metas, Sungai Belat dan sungai lakar. Disamping sungai, di sekitar Desa Penyengat terdapat beberapa danau dan 
tasik antara lain Tasik Bawah, Tasik Pulau Besar dan Danau Kebuk.

Masyarakat pesisir, masyarakat Desa Penyengat sebagian besar mengandalkan kehidupannya dari perairan baik sungai, muara sungai, danau, tasik, maupun laut. Namun karena keterbatasan sarana yang dimiliki, wilayah perairan yang masyarakat klaim sebagai wilayah mereka hanya sebatas wilayah sekitar pesisir pantai termasuk sungaisungai kecil yang berada di kawasan tersebut.

Tidak hanya kawasan perairan yang menjadi tumpuan masyarakat mencari nafkah, tetapi hutan disekitar mereka juga menjadi harapan pemenuhan. Hutan yang dimanfaatkan juga masih berkisar hutan ditepian sungai atau pesisir pantai.Tidak banyak kawasan hutan yang jauh dari tepian sungai atau tepian pantai yang mereka usahakan. Hal ini disebabkan juga karena keterbatasan tenaga dan kemampuan yang masyarakat miliki.

Luas wilayah adat Penyengat berjumlah 150.271,719 Ha, Saat ini di Desa Penyengat telah terjadi penguasaan kawasan hutan atas tanah berskala besar oleh perusahaan hutan tanaman industry, perusahaan perkebunan kelapa sawit dan pertambangan. Dengan rincian sebagai berikut :

1. HTI : 6 Perusahaan
a. PT. Uni Seraya
: 4.907,07 На
b. PT. RAPP
: 14.319,56 На
c. PT. Putra Riau Perkasa
: $\quad 379,67 \mathrm{Ha}$
d. PT. National Timber dan Forest Product
: 7.920,92 На
e. PT. Balai Kayang Mandiri
: 6.061,73 На
f. PT. Arara Abadi
: 25.861,80 На

2. HPH : 1 Perusahaan
a. PT. Triomas F. D. I
: 80.663,21 На

3. Perkebunan : 4 Perusahaan
a. PT. Trisetya Usaha Mandiri
: $8.109,38 \mathrm{Ha}$
b. PT. Triomas F. D I
: 10.242,20 На
C. KUD Jaya Subur
: $\quad 770,89 \mathrm{Ha}$
d. PT. Uni Seraya
: 11.355,99 На

4. Pertambangan : 1 Perusahaan

a. PT. Petro Selat (Perminyakan)

Perusahaan beroperasi tanpa mendahulukan prinsip FPIC (Free prior inform consent) atau yang disebut dengan keputusan bebas yang didahulukan, diinformasikan tanpa ada paksaan. Hal ini dapat dilihat dalam proses pemberian perizinan kepada investor seakan - akan tidak ada dampak negative kepada masyarakat. Terbukti ketika tidak ada sosialisasi terlebih dahulu kepada masyarakat tentang rencana pembangunan oleh perusahaan, salah satu dampak dari pembangunan perusahaan ini mengakibatkan 
terbatasnya wilayah kelola, pencemaran lingkungan dan hilangnya sumber- sumber mata pencaharian masyarakat. Ketergantungan masyarakat terhadap hutan sangat tinggi, hal ini dapat dilihat dari aktivitas masyarakat yang sebagian besar menjadikan hutan sebagai tempat mencari nafkah untuk menghidupi keluarga, selain hutan sungai dan laut juga menjadi sumber ekonomi bagi masyarakat desa penyengat untuk kehidupan sehari- hari.

Pada tanggal 15 Januari 2015 Pemerintah Kabupaten Siak, yang ditanda tangani oleh Bupati Siak Drs. H. Syamsuar, M.Si telah menetapkan Peraturan Daerah Kabupaten Siak Nomor 2 Tahun 2015 tentang Penetapan Kampung Adat Di Kabupaten Siak dan Pada Pasal 3 dijelaskan bahwa Kampung Penyengat menjadi Kampung Adat Asli Anak Rawa Penyengat di Kecamatan Sungai Apit. Dengan adanya penetapan tersebut maka Suku Asli Anak Rawa memiliki peluang untuk mendapatkan Perlindungan Hukum atas hak-haknya.

Permasalahan yang terjadi adalah bagaimana masyarakat suku asli anak rawa memaknai semakin berkurangnya wilayah kelola, hilangnya sumber-sumber mata pencaharian dan mengorganisir diri untuk merebut peluang hak kelola. Permasalahan lahan adat dan masyarakat adat diatas maka peneliti merasa perlu mengkaji lebih dalam tentang Penetapan Wilayah Adat dan Masyarakat Hukum Adat Desa Penyengat Kecamatan Sungai Apit Kabupaten Siak Berdasarkan Peraturan Menteri Dalam Negeri Nomor 52 Tahun 2014 Tentang Pedoman Pengakuan dan Perlindungan Masyarakat Hukum Adat.

Jenis penelitian ini adalah sosiologis, sehingga sumber data yang digunakan adalah data primer dari wawancara, data sekunder dari perpustakaan dan data tersier dari kamus, media, dan ensiklopedia. Teknik pengumpulan data dilakukan dengan observasi, wawancara, dan kajian kepustakaan.

Terhadap kajian mengenai penelitian ini, pernah dilakukan oleh Santoso dan Ajeng Safitri, ${ }^{10}$ dengan judul Kesadaran Esensial Motivasi Belajar Agama Islam pada Kaum Mualaf Suku Akit. Perbedaan kajian yang dilakukan oleh Santoso dan Ajeng Safitri terdapat pada tinjauan dan sasaran penelitian. Tinjauan dan sasaran penelitian yang dilakukan oleh Santoso dan Ajeng Safitri adalah pada motivasi belajar agama, yang lebih pada tinjauan keilmuan sosiologis, sementara penulis melakukan penelitian ini dengan tinjauan dan sasaran pada Penetapan Wilayah Adat dan Masyarakat Hukum Adat.

\section{Penetapan Wilayah Adat Suku Asli Anak Rawa di Kampung Penyengat Kecamatan Sungai Apit Berdasarkan Peraturan Menteri Dalam Negeri Nomor 52 Tahun 2014 Tentang Pedoman Pengakuan dan Perlindungan Masyarakat Hukum Adat}

Kabupaten Siak sebagai daerah yang dahulu pernah menjadi suatu Negara telah mempunyai struktur dan istilah pemerintahan tersendiri mulai dari pemerintahan

\footnotetext{
${ }^{10}$ Santoso dan Ajeng Safitri, Kesadaran Esensial Motivasi Belajar Agama Islam pada Kaum Mualaf Suku Akit, An - Nafs: Jurnal Fakultas Psikologi 2019, Volume 13, Nomor 1, hlm. 1
} 
Provinsi sampai pada pemerintahan yang terendah. Saat ini organisasi pemerintahan yang terendah disebut dengan "Kampung” dan "Kampung Adat”. Fenomena pemerintahan desa adat dalam sejarah tata pemerintahan di Kabupaten Siak mengalami pasang surut akibat pengaruh kebijakan negara yang sentralistik mengatur kehidupan masyarakat lokal. Adanya kebijakan negara melalui Undang-Undang Nomor 6 Tahun 2014 tentang Desa membuka ruang bagi daerah untuk menentukan bentuk pemerintahan desa yang sesuai dengan corak dan karekteristik budaya lokal masyarakat setempat, termasuk bagi Pemerintah Kabupaten Siak.

Berdasarkan hasil wawancara dengan Ketua Komisi I DPRD Kabupaten Siak terkait dengan pembentukan kampung adat menjelaskan bahwa, Peraturan Daerah Kabupaten Siak Nomor 2 Tahun 2015 tentang Penetapan Kampung Adat di Kabupaten Siak sedikit demi sedikit pemerintah Kabupaten Siak mulai mereduksi bentuk pemerintahan lama yang dianggap berkontribusi dalam penyelenggaraan pemerintahan daerah sekaligus mengurangi beban besar negara dalam hal kemandirian dan permasalahan daerah. Usaha untuk mengembalikan format pemerintahan desa adat/kampung adat sejalan dengan semangat dari perumusan Pasal 18B ayat (2) yang secara tegas menyatakan bahwa "Negara mengakui dan menghormati keberadaan masyarakat hukum adat dan hakhak tradisionalnya sepanjang masih ada dan sesuai dengan perkembangan masyarakat dan prinsip-prinsip Negara Kesatuan Republik Indonesia, yang diatur dalam undangundang”. ${ }^{11}$

Selanjutnya, sebagai landasan filosofisnya bahwa pembentukan Peraturan Daerah ini adalah bertolak dari konsepsi negara mengakui dan menghormati kesatuan masyarakat hukum adat beserta hak tradisionalnya sepanjang masih hidup dan sesuai dengan perkembangan masyarakat dan prinsip Negara Kesatuan Republik Indonesia, yang diatur dalam Undang-Undang. Landasan sosiologis pembentukan Peraturan Daerah ini didasarkan pada upaya untuk mengembalikan nilai adat masyarakat lokal dan peranan tokoh masyarakat adat serta untuk menghidupkan kembali nilai dan norma adat di Kampung Adat atau nama lainnya perlu dilakukan Penetapan Kampung Adat di Kabupaten Siak. ${ }^{12}$

Berdasarkan hasil wawancara dengan Kepala Dinas Pemberdayaan Masyarakat dan Kampung (DPMK) Kabupaten Siak terkait dengan keberadaan dan pemberdayaan kampung adat menjelaskan bahwa, Kampung yang dimaksud dalam Peraturan Daerah tentang Penetapan Kampung Adat di Kabupaten Siak, Perda No 2 Tahun 2015 ini adalah kesatuan masyarakat hukum yang memiliki batas wilayah yang berwenang untuk mengatur dan mengurus urusan Pemerintahan, kepentingan masyarakat setempat berdasarkan

\footnotetext{
${ }^{11}$ Hasil wawancara dengan Ketua Komisi I DPRD Kabupaten Siak, Ibu Hj. Gustimar, S.Pd. Tanggal 20 Maret 2018, Pukul 14. ${ }^{00}$ Wib di Kantor DPRD Kabupaten Siak.

${ }^{12}$ Ibid.,
} 
prakarsa masyarakat, hak asal usul, dan/atau hak tradisional yang diakui dan dihormati dalam sistem Pemerintahan Negara Kesatuan Republik Indonesia. Adapun Kampung Adat adalah susunan asli yang mempunyai hak asal usul berupa hak mengurus wilayah dan mengurus kehidupan masyarakat hukum adatnya, khususnya adat Melayu Siak. ${ }^{13}$

Ditinjau dari landasan pembentukan peraturan perundang-undangan, baik landasan filosofis dan sosiologis dalam Peraturan Daerah ini memiliki landasan argumentasi hukum yang kuat. Dalam konteks NKRI, landasan filosofis pembentukan Peraturan Daerah ini harus mengacu pada nilai-nilai Pancasila yang merupakan pandangan hidup, cita-cita bangsa, falsafah atau jalan kehidupan dalam kehidupan berbangsa dan bernegara. Adapun landasan sosiologis menghendaki ketentuan-ketentuan dalam Peraturan Daerah ini harus mencerminkan kenyataan hidup dalam masyarakat dan merupakan aspirasi masyarakat. Hukum yang dibuat harus sesuai dengan hukum yang hidup dalam masyarakat khususnya masyarakat Kabupaten Siak.

Berdasarkan hasil wawancara dengan Ketua Lembaga Adat Melayu Kabupaten Siak terkait dengan pembentukan dan penetapan kampung adat di Kabupaten Siak mengatakan bahwa Pemerintah Kabupaten Siak telah menetapkan 8 (delapan) Kampung Adat di Kabupaten Siak yaitu:

1. Kampung Lubuk Jering menjadi Kampung Adat Lubuk Jering di Kecamatan Sungai Mandau

2. Kampung Tengah menjadi Kampung Adat Kampung Tengah di Kecamatan Mempura

3. Kampung Kuala Gasib menjadi Kampung Adat Kuala Gasib di Kecamatan Koto Gasib

4. Kampung Penyengat menjadi Kampung Adat Asli Anak Rawa Penyengat di Kecamatan Sungai Apit

5. Kampung Minas Barat menjadi Kampung Adat Sakai Minas di Kecamatan Minas

6. Kampung Mandi Angin menjadi Kampung Adat Sakai Mandi Angin di Kecamatan Minas

7. Kampung Bekalar menjadi Kampung Adat Sakai Bekalar di Kecamatan Kandis

8. Kampung Libo Jaya menjadi Kampung Adat Sakai Libo Jaya di Kecamatan Kandis. ${ }^{14}$

Selanjutnya disampaikan bahwa penetapan 8 (delapan) Desa di atas dari beberapa Desa di Kabupaten Siak dikarenakan masyarakat pada beberapa Desa tersebut telah menyatakan kesiapan untuk ditetapkan menjadi Desa Adat yang disebut dengan

\footnotetext{
${ }^{13}$ Hasil wawancara dengan Kepala Dinas Pemberdayaan Masyarakat dan Kampung (DPMK) Kabupaten Siak, Bapak Yurnalis, Tanggal 21 Maret 2018, Pukul 10. ${ }^{30}$ Wib di Kantor DPMK Kabupaten Siak.

${ }^{14}$ Hasil wawancara dengan Ketua Lembaga Adat Melayu Riau (LAMR) Kabupaten Siak, Bapak H. Nazir Khatan, Tanggal 22 Maret 2018, Pukul 15. ${ }^{00}$ Wib di Kantor Lembaga Adat Melayu Kabupaten Siak.
} 
“Kampung Adat”. Pembentukannya dengan mempertimbangkan aspirasi dan kesiapan masyarakat di masing-masing Desa. Dikemudian hari dimungkinkan saja penambahan jumlah Kampung Adat di Kabupaten Siak dengan kajian dan persiapan yang lebih baik. ${ }^{15}$

Berdasarkan hasil wawancara dengan Penghulu Kampung Penyengat terkait dengan penetapan dan perangkat kampung Adat menjelaskan bahwa sistem pemerintahan Kampung Adat diatur dalam Pasal 4 Peraturan Daerah Kabupaten Siak Nomor 2 Tahun 2015 tentang Penetapan Kampung Adat memiliki ciri dan kriteria Pemerintah Kampung Adat yang terdiri dari: Penghulu dan Perangkat Kampung Adat. Perangkat Kampung Adat terdiri dari Sekretariat Kampung Adat, Unsur kewilayahan dan Pelaksana teknis lapangan. Sekretariat Kepenghuluan Adat terdiri dari Kerani sebagai pimpinan sekretariat dan Juru tulis, staf, atau unsur pembantu kerani. Unsur kewilayahan meruupakan Pembantu Penghulu yakni Kadus, Rukun Kampung dan Rukun Tetangga. Pelaksana teknis lapangan yaitu petugas Kampung Adat yang melakukan suatu tugas tertentu dalam perkampungan Adat seperti urusan agama, keamanan, pengairan, pertanian, pemadaman kebakaran hutan dan lahan atau urusan lain yang jumlahnya disesuaikan dengan kebutuhan dan kondisi sosial budaya masyarakat setempat. ${ }^{16}$

Berdasarkan hasil wawancara dengan Camat Sungai Apit terkait dengan penetapan kampung adat yang ada di Kabupaten Siak menjelaskan bahwa ditinjau dari pendekatan sejarah, sistem pemerintahan "Kampung Adat” di Kabupaten Siak, tidak persis sama dengan sistem pemerintahan yang dikembangkan pada masa Pemerintahan Kerajaan Siak. Jika pada masa itu, dikenal sistem pemerintahan kepenghuluan yang dipimpin oleh "Penghulu” dengan dibantu oleh Sangko Penghulu (wakil Penghulu), Malim Penghulu (pembantu urusan kepercayaan/agama); dan Lelo Penghulu (pembantu urusan adat sekaligus berfungsi sebagai Hulubalang), namun dalam Peraturan Daerah ini sistem pemerintahannya disebut "Pemerintahan Kampung Adat" dengan perangkat pemerintahan yang hampir sama dengan perangkat "Pemerintahan Desa” pada umumnya, bahkan juga tidak terlalu berbeda secara signifikan dengan "Pemerintahan Kampung" yang ada di Kabupaten Siak. Hal ini bisa dilihat dari perangkat desa yang diatur dalam Pasal 48 Undang-Undang Nomor 6 Tahun 2014 yang menyebutkan: Perangkat Desa terdiri atas Sekretariat Desa, Pelaksana Kewilayahan dan pelaksana Teknis. ${ }^{17}$

Jika mengacu pada Pasal 107 Undang-Undang tersebut dinyatakan: "Pengaturan dan penyelenggaraan Pemerintahan Desa Adat dilaksanakan sesuai dengan hak asal usul dan hukum adat yang berlaku di Desa Adat yang masih hidup serta sesuai dengan

\footnotetext{
15 Ibid.,

${ }^{16}$ Hasil wawancara dengan Penghulu Kampung Penyengat, Bapak Abet, SH. Tanggal 17 Maret 2018, Pukul 15. ${ }^{15}$ Wib di Kantor Kepala Kampung Penyengat Kecamatan Sungai Apit-Kabupaten Siak.

${ }^{17}$ Hasil wawancara dengan Camat Sungai Apit, Bapak Suparni, S. Sos. Tanggal 26 Maret 2018, Pukul 11. ${ }^{10}$ Wib di Kantor Camat Sungai Apit-Kabupaten Siak.
} 
perkembangan masyarakat dan tidak bertentangan dengan asas penyelenggaraan Pemerintahan Desa Adat dalam prinsip Negara Kesatuan Republik Indonesia”.

Berdasarkan hasil wawancara dengan Ketua Adat terkait dengan penetapan kampung adat di Kampung Penyengat menjelaskan bahwa, Pelaksanaan "Kampung Adat” di Kabupaten Siak memerlukan dukungan dari segala aspek baik instrumen pelaksana maupun dari sisi substansi dari kehidupan adat masyarakat yang diyakini sebagai aturan hidup yang mengikat. Walaupun pemerintahan "Kampung Adat” yang dikembangkan saat ini tidak persis sama dengan sistem pemerintahan “Kepenghuluan” yang pernah dikenal masyarakat Kabupaten Siak, namun perbedaan ini dapat dipahami mengingat pengaruh perkembangan zaman dan globalisasi dalam kehidupan sosial masyarakat Siak sehingga merobah pola perilaku dan cara berpemerintahan yang diterapkan. ${ }^{18}$

Berdasarkan hasil wawancara dengan Ketua Suku Asli Anak Rawa terkait dengan pembentukan dan penetapan kampung adat di Kabupaten Siak menjelaskan bahwa pembentukan kampung adat memang terdapat perbedaan antara sistem "Pemerintahan Kampung Adat” yang berlaku saat ini di Kabupaten Siak dengan sejarah Pemerintahan sebelumnya "Kepenghuluan Siak" sebelumnya sehingga tidak sesuai dengan susunan aslinya, namun hal tersebut tetap saja dibenarkan dan tidak bertentangan dengan semangat yang terkandung dalam Undang-Undang ini. Pemerintahan Desa Adat menyelenggarakan fungsi permusyawaratan dan Musyawarah Desa Adat sesuai dengan susunan asli Desa Adat atau “dibentuk baru” sesuai dengan prakarsa masyarakat Desa Adat. Kampung adat pada dasarnya melakukan tugas yang hampir sama dengan Kampung sebelumnya, sedangkan perbedaannya hanyalah dalam pelaksanaan hak asal usul. Permasalahannya adalah apakah sistem "Pemerintahan Kampung Adat” dalam Peraturan Daerah ini telah benar-benar didasarkan prakarsa masyarakat "Kampung Adat” yang telah ditetapkan atau lebih didasarkan pada pandangan politis dari Pemerintah Kabupaten Siak. ${ }^{19}$

Pasal 108 yang menyebutkan bahwa Pemerintahan Desa Adat menyelenggarakan fungsi permusyawaratan dan Musyawarah Desa Adat sesuai dengan susunan asli Desa Adat atau dibentuk baru sesuai dengan prakarsa masyarakat Desa Adat. Kata dibentuk baru mengandung makna boleh saja sistem pemerintahannya baru atau tidak sama dengan susunan asli Desa Adat, asalkan sesuai dengan prakarsa masyarakat Desa Adat.

Berdasarkan observasi penelitian dilapangan tidak ditemukan dasar kajian yang mendalam terkait penetapan Kampung Adat berikut perangkat pemerintahannya sesuai dengan hak asal usul dan hukum adat yang berlaku dibeberapa Kampung Adat yang telah ditetapkan. Meskipun pembentukan Peraturan Daerah ini telah dilengkapi dengan kajian

\footnotetext{
${ }^{18}$ Hasil wawancara dengan Ketua Suku Asli Anak Rawa, Bapak Dom, Tanggal 17 Maret 2018, Pukul $11 .{ }^{10}$ Wib di Kampung Penyengat Kecamatan Sungai Apit-Kabupaten Siak.

${ }^{19}$ Hasil wawancara dengan Ketua Adat Asli Anak Rawa, Bapak Kiat, Tanggal 17 Maret 2018, Pukul 12. ${ }^{00}$ Wib di Kampung Penyengat Kecamatan Sungai Apit-Kabupaten Siak.
} 
Naskah Akademis sebagaimana yang ditetapkan dalam Undang-Undang Nomor 12 Tahun 2011 tentang Pembentukan Peraturan Perundang-undangan, namun pembahasannya masih sederhana dan belum menggambarkan arah kebijakan yang komprehensif terkait model Kampung Adat yang berdasarkan susunan asli Desa Adat atau pembentukan suatu sistem yang baru sesuai dengan prakarsa masyarakat. ${ }^{20}$

Argumentasi diatas diakui pula dalam Pasal 6 ayat (2) Peraturan Daerah Kabupaten Siak Nomor 2 Tahun 2015 yang berbunyi: “Kampung adat pada dasarnya melakukan tugas yang hampir sama dengan Kampung, sedangkan perbedaannya pelaksanaan hak asal usul, menyangkut kelestarian sosial, pengaturan dan pengurusan wilayah adat, sidang perdamaian adat, pemeliharaan ketentraman dan ketertiban bagi masyarakat hukum adat, serta pengaturan pelaksanaan pemerintahan berdasarkan susunan asli”.

Berdasarkan pemaparan di atas, dapat disimpulkan bahwa pelaksanaan pembentukan Peraturan Daerah Kabupaten Siak Nomor 2 Tahun 2015 tentang Penetapan Kampung Adat Di Kabupaten Siak telah sesuai dengan tata cara pembentukan peraturan perundang-undangan yang berlaku, meskipun belum secara optimal dan mendasar dapat terlaksana. Pengaturan Peraturan Daerah tersebut yang paling menonjol adalah peralihan penyebutan nama desa menjadi "Kampung Adat" dan kepala desa disebut sebagai "Penghulu”. Penetapan "Kampung Adat” dengan instrumen hukum berupa Peraturan daerah telah sesuai dengan amanat Pasal 98 ayat (1) Undang-Undang Nomor 6 Tahun 2014 tentang Desa yang menyebutkan bahwa: "Desa Adat ditetapkan dengan Peraturan Daerah Kabupaten/Kota”. Meskipun demikian, Peraturan Daerah tersebut masih memiliki kelemahan-kelemahan dalam pelaksanaannya karena memerlukan peraturan teknis yang sampai saat ini belum jelas pengaturannya.

\section{Hambatan Dalam Pelaksanaan Penetapan Wilayah Adat Suku Asli Anak Rawa di Kampung Penyengat Kecamatan Sungai Apit Berdasarkan Peraturan Menteri Dalam Negeri Nomor 52 Tahun 2014 Tentang Pedoman Pengakuan dan Perlindungan Masyarakat Hukum Adat}

Berdasarkan Perda Nomor 2 Tahun 2015 tentang Penetapan Kampung Adat, Kabupaten Siak menetapkan delapan Kampung adat. Yakni, Kampung Adat Lubuk Jering, di Kecamatan Sungai Mandau, Kampung Adat Kampung Tengah, Mempura, Kampung Adat Kuala Gasip, Koto Gasip. Kampung Adat Asli Anak Rawa Penyengat, Sungai Apit. Selanjutnya, Kampung Adat Sakai Minas, Kampung Adat Sakai Mandi Angin, masingmasing berada di Kecamatan Minas, lalu Kampung Adat Sakai Bekalar dan Sakai Libo Jaya di Kecamatan Kandis. Akan tetapi dalam pelaksanaannya masih banyak terjadi hambatan-hambatan. Adapun beberapa hambatan dalam pelaksanaan pembentukan

\footnotetext{
${ }^{20}$ Berdasarkan hasil observasi Penulis di Kampung Penyengat tanggal 17 Maret 2018
} 
Peraturan Daerah Kabupaten Siak Nomor 2 Tahun 2015 tentang Penetapan Kampung Adat Di Kabupaten Siak.

Berdasarkan hasil wawancara dengan Ketua Komisi I DPRD Kabupaten Siak terkait kendala dalam pembentukan Kampun Adat di Kabupaten Siak adalah belum tersedianya payung hukum berupa Peraturan Daerah Provinsi berikut peraturan pelaksanaannya terkait Kampung Adat. ${ }^{21}$ Berdasarkan Pasal 109 Undang-Undang Nomor 6 Tahun 2014 tentang Desa ditegaskan bahwa “Susunan kelembagaan, pengisian jabatan, dan masa jabatan Kepala Desa Adat berdasarkan hukum adat ditetapkan dalam peraturan daerah Provinsi”. Undang-Undang ini secara tegas memberi atribusi kewenangan kepada Pemerintah Provinsi untuk mengatur lebih lanjut susunan kelembagaan, pengisian jabatan, dan masa jabatan Kepala Desa Adat, jadi bukan pada Pemerintah Kabupaten. ${ }^{22}$

Permasalahannya dalam Peraturan Daerah Kabupaten Siak Nomor 2 Tahun 2015 telah mengatur hal sebenarnya bukan kewenangan Kabupaten, melainkan kewenangan Provinsi. Hal ini dapat dilihat ketentuan Pasal 9 ayat (1) huruf e terkait dengan tugas Lembaga Adat Kampung Adat untuk memilih Penghulu sesuai peraturan yang berlaku, padahal berdasarkan Undang-Undang telah ditegaskan bahwa pengisian jabatan Kepala Desa Adat ditetapkan dalam peraturan daerah Provinsi. Hal ini tentu saja berpotensi memunculkan potensi pertentangan antara Peraturan Daerah Provinsi dengan Peraturan Daerah Kabupaten mengenai hal tersebut. ${ }^{23}$

Berdasarkan hasil wawancara dengan Kepala Dinas Pemberdayaan Masyarakat dan Kampung (DPMK) Kabupaten Siak terkait kendala pembentukan dan penetapan kampung adat di Kabupaten Siak adalah Minimnya referensi dan kajian Kampung Adat yang sesuai dengan hak asal usul dan hukum adat yang berlaku di Kabupaten Siak. Dalam implementasinya kampung adat belum bisa difungsikan, karena terbentur kode desa dari pemerintah pusat yang belum juga turun hingga saat ini. Ditambah lagi belum terbitnya Perda Kampung Adat Provinsi Riau. Selain itu belum dikeluarkannya Permendagri tentang penataan desa adat membuat nasib delapan desa adat di Kabupaten Siak terkatung-katung. Perubahan "kode desa” dari desa ke desa adat untuk delapan Kampung Adat yang sudah ditetapkan tidak kunjung dikeluarkan Kemendagri. Belum dikeluarkannya "kode desa" adat ini menyebabkan pejabat Pemkab Siak kebingungan dalam menentukan tata kelola pemerintahan desa adat. Kampung adat tidak bisa melaksanakan pilkades, sebab kode desa adat belum juga kunjung diberikan sehingga saat ini masih dijabat oleh penanggung jawab (Pj), bahkan ada yang sudah hampir dua tahun dijabat oleh Pj. Akibatnya, kampungkampung adat mengalami stagnisasi bila ingin melakukan pilkades berdasarkan susunan

\footnotetext{
${ }^{21}$ Hasil wawancara dengan Ketua Komisi I DPRD Kabupaten Siak, Ibu Hj. Gustimar, S.Pd. Tanggal 20 Maret 2018, Pukul $14 .{ }^{00}$ Wib di Kantor DPRD Kabupaten Siak.

${ }^{22}$ Ibid.,

${ }^{23}$ Ibid.,
} 
asli, mereka (kampung adat) belum mendapatkan pengakuan dari Kemendagri. Sedangkan jika melakukannya dengan sistem pemerintahan desa administratif tidak mungkin lagi karena sudah ditetapkan menjadi desa/kampung adat. ${ }^{24}$

Jika mengacu pada Pasal 107 dan 108 Undang-Undang Nomor 6 Tahun 2014 dapat dipahami bahwa pengaturan dan penyelenggaraan Pemerintahan Desa Adat dilaksanakan sesuai dengan hak asal usul dan hukum adat yang berlaku di Desa Adat yang masih hidup serta sesuai dengan perkembangan masyarakat dan tidak bertentangan dengan asas penyelenggaraan Pemerintahan Desa Adat dalam prinsip Negara Kesatuan Republik Indonesia”. Disamping itu, “Pemerintahan Desa Adat menyelenggarakan fungsi permusyawaratan dan Musyawarah Desa Adat sesuai dengan susunan asli Desa Adat atau dibentuk baru sesuai dengan prakarsa masyarakat Desa Adat”. Ketentuan tersebut tentu saja menghendaki adanya kajian yang komprehensif untuk menentukan Kampung Adat di Kabupaten Siak apakah betul-betul berakar dari hak asal usul dan hukum adat yang berlaku di masyarakat Siak atau merupakan konsep pengembangan sesuai dengan kondisi kekinian masyarakat Kabupaten Siak namun tetap berakar dari hak asal usul dan hukum adat yang dimaksud. ${ }^{25}$

Berdasarkan hasil observasi penelitian ini, penulis juga tidak mendapatkan hasil kajian komprehensif sebagaimana yang dijelaskan diatas. Meskipun Peraturan Daerah Kabupaten Siak Nomor 2 Tahun 2015 telah dilengkapi dengan naskah akademis, namun substansinya belum komprehensif dan masih bersifat umum. Kondisi ini juga diperkuat berdasarkan hasil wawancara dengan pihak terkait yang mengungkapkan tentang minimnya referensi konsep Kampung Adat yang pernah ada di kampung tersebut, bahkan sangat sulit didapat karena tidak adanya dokumentasi penerapan adat-adat terdahulu, tokoh-tokoh adat yang telah wafat, dan telah lamanya hilang adatistiadat terkait sistem pemerintahan Kampung Adat dalam praktek kehidupan masyarakat setempat akibat pengaruh praktek kebijakan Pemerintah Pusat yang menyeragamkan sistem Pemerintahan Desa.

Berdasarkan hasil wawancara dengan Camat Sungai Apit terkait kendala pembentukan dan penetapan kampung adat di Kabupaten Siak adalah Minimnya pengetahuan aparatur pemerintahan dan masyarakat terhadap Kampung Adat. Hal ini diketahui bahwa pengetahuan hukum aparatur pemerintahan maupun masyarakat sangat mempengaruhi efektivitas berlakunya suatu kaidah hukum yang diberlakukan dalam kehidupan masyarakat. ${ }^{26}$ Berdasarkan hasil wawancara tersebut dijelaskan bahwa pemahaman mendalam mengenai sistem pemerintahan Kampung Adat di Kabupaten

\footnotetext{
${ }^{24}$ Hasil wawancara dengan Kepala Dinas Pemberdayaan Masyarakat dan Kampung (DPMK) Kabupaten Siak, Bapak Yurnalis, Tanggal 21 Maret 2018, Pukul 10. ${ }^{30}$ Wib di Kantor DPMK Kabupaten Siak.

${ }^{25}$ Ibid.,

${ }^{26}$ Hasil wawancara dengan Ketua Lembaga Adat Melayu Riau (LAMR) Kabupaten Siak, Bapak H. Nazir Khatan, Tanggal 22 Maret 2018, Pukul 15. ${ }^{00}$ Wib di Kantor Lembaga Adat Melayu Kabupaten Siak.
} 
Siak hanya dimiliki oleh tokoh-tokoh masyarakat yang jumlahnya sangat sedikit, bahkan sudah sangat sepuh dan sedikit yang masih hidup. Sebaliknya, generasi muda masyarakat Kabupaten Siak saat ini sangat banyak yang tidak mengetahui tentang adat istiadat yang berlaku di kampungnya, apalagi terkait dengan sistem pemerintahannya, karena tidak mendapatkan contoh atau tauladan dari tetua adat mereka sehingga menyulitkan untuk memberikan pemahaman semula. Apalagi pemberlakuan sistem pemerintahan Kampung Adat masih baru, ketimbang pelaksanaan Pemerintahan Desa sebelumnya yang menyeragamkan sistem Pemerintahan Desa di semua daerah.Kondisi ini mengharuskan masyarakat lokal untuk lebih giat dan sungguh-sungguh untuk menggali kembali nilainilai adat yang berkembang agar pelaksanaan kampung adat kedepan dapat terealisasi secara utuh dan menyeluruh dalam segala aspek kehidupan masyarakat setempat. ${ }^{27}$

Berdasarkan hasil wawancara dengan Camat Sungai Apit terkait kendala pembentukan dan penetapan kampung adat di Kabupaten Siak adalah Belum optimalnya sosialisasi Peraturan Daerah terkait Kampung Adat. Di Kabupaten Siak sudah diterbitkan beberapa Peraturan Daerah yang terkait dengan sistem pemerintahan Kampung dan Kampung Adat, yaitu Peraturan Daerah Kabupaten Siak Nomor 1 Tahun 2015 tentang Perubahan Penamaan Desa Menjadi Kampung yang diundangkan pada tanggal 15 Januari 2015, Peraturan Daerah Kabupaten Siak Nomor 2 Tahun 2015 tentang Penetapan Kampung Adat Di Kabupaten Siak yang diundangkan pada tanggal 15 Januari 2015, dan Peraturan Daerah Kabupaten Siak Nomor 2 Tahun 2015 tentang Tata Cara Pengangkatan, Pelantikan Dan Pemberhentian Perangkat Kampung yang diundangkan pada tanggal 9 Maret 2015, dan Peraturan Daerah Kabupaten Siak Nomor 5 Tahun 2015 tentang Badan Permusyawaratan Kampung yang diundangkan pada tanggal 9 Maret 2015. Hal ini tentu saja berdampak terhadap masih lemahnya pemahaman masyarakat terhadap substansi dari peratauran perundang-undangan diatas, sehingga efektivitas pelaksanaanya menjadi terhambat. Apalagi Peraturan Daerah tersebut lebih banyak mengatur perihal "Pemerintahan Kampung” dan sangat sedikit mengatur perihal "Pemerintahan Kampung Adat”. Dengan demikian terjadi legal gap antara dassollen berupa kaidah hukum yang diatur dalam Peraturan Daerah tersebut dengan dassein berupa lemahnya implementasi ketentuan dimaksud dalam praktek kehidupam masyarakat Kabupaten Siak. ${ }^{28}$

Berdasarkan hasil wawancara dengan Penghulu Kampung Penyengat terkait kendala pembentukan dan penetapan kampung adat di Kabupaten Siak adalah memang Peraturan Daerah Nomor 2 Tahun 2015 tentang Penetapan Kampung Adat di Kabupaten Siak baru diundangkan oleh Pemerintah Kabupaten Siak mulai awal Tahun 2015, sehingga untuk melakukan sosialisasinya masih sangat terbatas. Ketentuan tentang desa

\footnotetext{
${ }^{27}$ Ibid.,

${ }^{28}$ Hasil wawancara dengan Camat Sungai Apit, Bapak Suparni, S. Sos. Tanggal 26 Maret 2018, Pukul 11. ${ }^{10}$ Wib di Kantor Camat Sungai Apit-Kabupaten Siak.
} 
adat dalam Undang-Undang Desa membawa harapan baru bagi pengakuan masyarakat adat di Kabupaten Siak. Namun dalam implementasinya, penetapan Kampung adat di Kabupaten Siak, Riau, masih menghadapi berbagai tantangan, antara lain belum adanya regulasi dalam pengubahan status Kampung menjadi Kampung adat, tidak adanya pengawasan dari pemerintah provinsi atau pusat, dan penyederhanaan proses penetapan Kampung adat ke dalam proses-proses administratif yang belum dapat merepresentasikan kompleksitas dinamika sosial masyarakat. ${ }^{29}$

\section{KESIMPULAN}

Penetapan Wilayah Adat Suku Asli Anak Rawa di Kampung Penyengat Kecamatan Sungai Apit Berdasarkan Peraturan Menteri Dalam Negeri Nomor 52 Tahun 2014 Tentang Pedoman Pengakuan dan Perlindungan Masyarakat Hukum Adat belum berjalan maksimal. Hal ini dibuktikan bahwa ditetapkannya Kampung Adat di Kabupaten Siak merupakan sistem pemerintahan lokal yang khas berdasarkan hak asal usul dan hak tradisional masyarakat di Kabupaten Siak. Peraturan yang telah dibuat tersebut sebagai bentuk pengakuan keberadaan Suku Asli Anak Rawa di kampung penyengat kecamatan sungai apit.

Hambatan pelaksanaan Penetapan Wilayah Adat Suku Asli Anak Rawa di Kampung Penyengat Kecamatan Sungai Apit Berdasarkan Peraturan Menteri Dalam Negeri Nomor 52 Tahun 2014 Tentang Pedoman Pengakuan dan Perlindungan Masyarakat Hukum Adat yaitu belum tersedianya payung hukum berupa Peraturan Daerah Provinsi berikut peraturan pelaksanaannya terkait Kampung Adat, minimnya referensi dan kajian Kampung Adat yang sesuai dengan hak asal usul dan hukum adat yang berlaku di Kabupaten Siak, minimnya pengetahuan aparatur pemerintahan dan masyarakat terhadap Kampung Adat, dan belum optimalnya sosialisasi Peraturan Daerah terkait Kampung Adat.

\section{DAFTAR PUSTAKA}

Asshiddiqie, Jimly, Komentar Atas UUD 1945, Jakarta: Sinar Grafika. 2009.

Nasution, Adnan Buyung, Pikiran dan Gagasan; Demokrasi Konsitusional, Jakarta: Kompas Media Nusantara, 2010.

Ni'matul Huda, Otonomi Daerah: Filosofi, Sejarah Perkembangan dan Problematika, dalam Republik Desa, Pergulatan Hukum Tradisional dan Hukum Modern dalam Desai Otonomi Desa, Bandung: PT. Alumni. 2010.

Rani, Nabella Puspa, Penerapan Sanksi Adat Melayu Kerajaan Siak Sri Indrapura Terhadap Kekerasan dalam Rumah Tangga, Jurnal Fikri 1, no. 2, (Desember 2016).

\footnotetext{
${ }^{29}$ Hasil wawancara dengan Penghulu Kampung Penyengat, Bapak Abet, SH. Tanggal 17 Maret 2018, Pukul 15. ${ }^{15}$ Wib di Kantor Kepala Kampung Penyengat Kecamatan Sungai Apit-Kabupaten Siak.
} 
Rosyada, Amrina, Esmi Warassih, dan Ratna Herawati, Perlindungan Konstitusional terhadap Kesatuan Masyarakat Hukum Adat dalam Mewujudkan Keadilan Sosial, Kanun Jurnal Ilmu Hukum 20, no. 1, (April 2018).

Rosyida, Hilmi, dan Bisariyadi (ed.), Inventarisasi dan Perlindungan Hak Masyarakat Hukum Adat, Jakarta: Komnas HAM, Mahkamah Konstitusi RI, dan Departemen Dalam Negeri, 2005.

Safitri, Santoso dan Ajeng, Kesadaran Esensial Motivasi Belajar Agama Islam pada Kaum Mualaf Suku Akit, An - Nafs: Jurnal Fakultas Psikologi 13, no. 1, (2019).

Salam, Safrin, Konstitusi Masyarakat Hukum Adat, Jakarta : PT Pradnya Paramita. 2008.

Simarmata, Rikardo, Pengakuan Hukum terhadap Masyarakat Adat di Indonesia, Jakarta: UNDP. 2006.

Zain, Mochamad Adib, dan Ahmad Siddiq, Pengakuan Atas Kedudukan dan Keberadaan Masyarakat Hukum Adat (MHA) Pasca dibentuknya Undang-Undang Nomor 6 Tahun 2014 Tentang Desa, Jurnal Penelitian Hukum 2, no. 2, (Juli 2015).

Undang-Undang Dasar Negara Republik Indonesia Tahun 1945

Peraturan Menteri Dalam Negeri No. 52 Tahun 2014 tentang pengakuan dan perlindungan masyarakat hukum adat

Peraturan Daerah Kabupaten Siak Nomor 1 Tahun 2015 tentang Perubahan Penamaan Desa Menjadi Kampung

Peraturan Daerah Kabupaten Siak Nomor 2 Tahun 2015 tentang Penetapan Kampung Adat Di Kabupaten Siak

Peraturan Daerah Kabupaten Siak Nomor 3 Tahun 2015 tentang Tata Cara Pengangkatan, Pelantikan Dan Pemberhentian Perangkat Kampung

Peraturan Daerah Kabupaten Siak Nomor 5 Tahun 2015 tentang Badan Permusyawaratan Kampung 